\title{
PEMIKIRAN ISLAM TENTANG HUBUNGAN NEGARA DENGAN AGAMA
}

\section{Nasaruddin}

STAIN Datokarama Palu, Jl. Diponegoro 23 Palu

e-mail: n_nasaruddin@yahoo.com

\section{Abstract}

A study of relationship between state and religion includes three paradigms: integralistic, symbiotic, and secularistic, which are products of legal reasoning to Quranic messages in the context of human history. In the case of Indonesia, it embraces Pancasila, which is neither based on religious nor secular systems. However, muslim communities in Indonesia become political targets due to the factors which include the weakness of Islamic politics that is uprooted from Islamic fundamental values in terms of political aspirations, and the application of western democracy that is not compatible with the traditions and cultures of Indonesia.

$$
\begin{aligned}
& \text { إن التفكر فكرة إسلامية فى الدولة و الدين هى جزء لاء يتجزء من الفكر }
\end{aligned}
$$

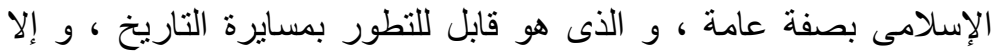

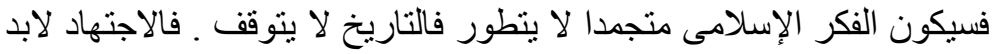

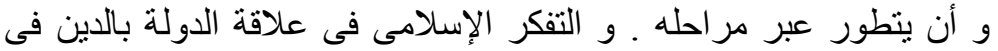

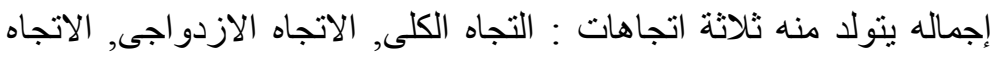

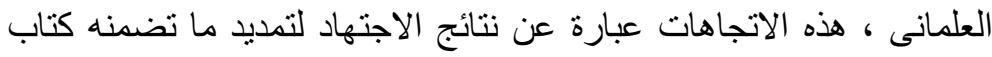

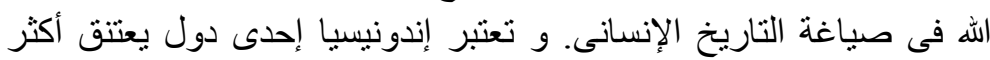

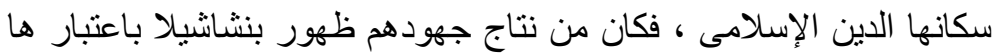

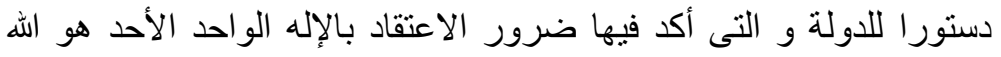

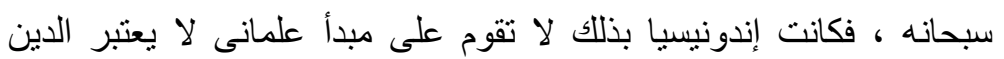

$$
\begin{aligned}
& \text { فكانت الأمة الأسلامية فى إندونيسيا تلعب دورا فعالا فى طرد المستعمرين } \\
& \text { الأوربيين من هذا الوطن. - الأنس }
\end{aligned}
$$

Kata Kunci: pemikiran Islam, Negara, agama 


\section{PENDAHULUAN}

Agama diturunkan bukanlah merupakan pembatas dan penghalang manusia untuk berbuat kebaikan, saling mengenal dan saling menolong, melainkan sebagai khazanah dan rahmat agar kehidupan manusia dinamis dan tidak monoton. Oleh karena itu, memaksakan suatu agama dengan cara apa pun kepada orang lain selain bertentangan dengan misi dan ajaran agama itu sendiri, juga merupakan sumber konflik dan penderitaan manusia serta kerusakan di muka bumi.

Dengan demikian, komitmen seseorang terhadap suatu agama terletak pada sejauh mana seseorang dalam membangun, berkarya, berperadaban, menjaga dan menyelamatkan kehidupan umat manusia dan lingkungan hidup serta mengembangkan perdamaian di dunia. Agama juga tidak mentolerir bahkan berupaya mcncegah orang-orang yang berbuat kerusakan dan pertumpahan darah yang akan menjatuhkan harkat dan martabat kemanusiaan.

Adalah doktrin yang tidak dapat dipertanggungjawabkan jika misi suatu agama memaksakan seseorang untuk mengikuti agama tertentu. Agama diturunkan bukan untuk mempolarisasi manusia atau untuk menghakimi, melainkan memberi arah pencarian kebenaran yang modelnya mungkin berbeda-beda. Sebaliknya, pemaksaan suatu agama justru dapat menimbulkan persoalan karena dengan cara itu agama bukannya sebagai rnoral atau aset pembangunan melainkan sebagai justifikasi sikap bermusuhan dan pelanggaran terhadap perikemanusiaan. Begitu pula adanya keyakinan terhadap berbagai agama di dunia menjadi bukti yang paling asasi bahwa secara kodrati manusia membutuhkan pedoman hidup yang berdimensi spiritual dan transendental, juga sekaligus membutuhkan tujuan hidup yang paling hakiki yaitu kebahagiaan dunia dan akhirat (Tabroni dan Arifin, 1994:1-2).

Dalam pandangan agama, menurut Watt sebagaimana dikutip Efendi (1996:95), hampir setiap muslim meyakini akan pentingnya prinsip-prinsip Islam dalam kehidupan politik. Akan tetapi bagaimana pendapat ini dituangkan ke dalam bentuk kehidupan politik yang lebih ril masih terdapat perbedaan pendapat. Sejauh yang dapat ditangkap dari perjalanan pemikiran dan aktivitas politik Islam, tidak ada kata sepakat, khususnya menyangkut bentuk dan isi hubungan antara Islam dan sistem politik modern (demokrasi). 
Berdasarkan atas uraian tersebut, fokus pembahasan dalam tulisan ini adalah bagaimana hubungan negara dengan agama serta pengaruhnya dalam aspek kehidupan?

\section{KAJIAN TEORITIS}

Dalam kerangka determinasi antropologis, manusia membutuhkan struktur kehidupan yang disebut dengan polis atau negara (state). Meskipun demikian, kebutuhan manusia terhadap politik pada bentuknya yang konkrit, tidak serta merta terbentuk menjadi struktur kenegaraan dalam tatanannya yang sudah modern seperti saat ini. Struktur kenegaraan mengalami proses evolusi politik dari bentuk yang sangat sederhana berupa kumpulan (bands), suku (tribes), chiefrom dan terakhir negara (state) (Tabroni dan Arifin, 1994:37).

Hal ini memberi kesan bahwa karena adanya kesamaan dan kesatuan langkah yang muncul di tengah-tengah masyarakat untuk membentuk suatu kelompok dalam upaya mencapai tujuan bersama, lahirlah suatu kelompok masyarakat yang akhirnya berkembang menjadi sebuah negara.

Sementara itu, dari tujuan kesejarahan, negara dalam pengertian sekarang boleh dikatakan merupakan gejala yang relatif muncul belakangan. Ketika zaman Yunani kuno sesungguhnya manusia sudah menyadari arti pentingnya negara bagi manusia, tetapi bentuk negara yang ada dalam pandangan mereka tidak lebih luas dari negara-negara kota (Haricahyono, 1986).

Negara dalam pengertian yang sangat sederhana ketika itu diperlukan untuk mencapai perkembangan manusia dalam peradabannya, terutama keinginan masyarakat untuk mengatur sendiri berbagai kepentingannya, baik politik, ekonomi, maupun sosial budaya berdasarkan aturan-aturan yang dibuat oleh masyarakat itu sendiri. Tampaknya, satu-satunya dasar pertimbangan yang digunakan adalah teori perjanjian masyarakat.

Tentang teori perjanjian masyarakat ini tokoh-tokohnya yang banyak dikenal ialah Plato, Epicurus, Sisero, St. Agustinus, Huge Grotius, Immanual Kant (Haricahyono, 1986).

Seperti halnya pandangan Plato mengenai asal mula Negara, sebagaimana dikutip oleh Haricahyono (1986), bahwa negara itu muncul karena adanya berbagai kebutuhan dan keinginan manusia 
semata-mata. Mengingat kebutuhan dan keinginan manusia itu tidak mau mereka harus bekerjasama agar keinginan dan kebutuhan yang saling berbeda itu dapat terhindarkan.

Adapun dalam pandangan Islam, negara adalah suatu kehidupan berkelompok, manusia yang mendirikannya bukan saja atas dasar perjanjian bermasyarakat (kontrak sosial), tetapi juga atas dasar fungsi manusia sebagai khalifah Allah di bumi yang mengemban kekuasaan sebagai amanah-Nya. Oleh karena itu, manusia dalam menjalani hidup ini harus sesuai dengan perintah-perintah-Nya dalam rangka mencapai kesejahteraan, baik di dunia maupun di akhirat (Azhari, 1992:12).

Pandangan tersebut mengisyaratkan pentingnya menegakkan sebuah masyarakat yang adil berdasarkan etika agar manusia dapat mencapai kesejahteraan sehingga dalam menjalankan amanah Allah di muka bumi sesuai dengan dasar dan petunjuk Islam.

Di sisi lain, suatu hal yang tidak mungkin dihindari dalam membicarakan negara dalam Islam adalah bahwa pertumbuhan dan perkembangan agama itu bersamaan dengan perkembangan sistem politik sejak Rasulullah saw. berhijrah dari Mekah ke Yastrib yang kemudian diubah namanya menjadi Madinah (Madjid dalam Rahman, 1994:588).

Dalam kaitan inilah dalam sejarah Islam, negara dan pemerintahan yang pertama dapat diamati dengan dua pendekatan. Pertama, pendekatan normatif Islam yang menekankan pada pelacakan terhadap nas $\square-n a s \square$ Alquran dan sunah nabi yang mengisyaratkan adanya praktek pemerintahan yang dilakukan oleh nabi dalam rangka siyâsat syar'iyyah. Kedua, pendekatan deskriptifhistoris dengan mengidentikkan tugas-tugas negara dan pemerintahan (Pulungan, 1997:77).

Meskipun demikian, dari berbagai konteks ayat-ayat Alquran walaupun terdapat banyak referensi mengenai kekuasaan dan otoritas, tetapi dari semua referensi tersebut belum dapat disimpulkan definisi dari sebuah negara yang ideal (Al-Ghazâlî, 1956:64).

Dari pemikiran-pemikiran di atas dapat dipahami bahwa suatu negara terbentuk bukan saja karena adanya kontak sosial di antara manusia, tetapi lebih dari itu pandangan Islam justru memandang secara esensi tentang adanya fungsi manusia sebagai khalifah Allah di bumi yang mengemban kekuasaan sebagai sebuah amanah. 
Sekitar Pemikiran Islam tentang Hubungan Negara dengan Agama

Dalam kaitan dengan kehidupan bernegara dan beragama, tidak satu pun manusia yang sanggup meraih kesejahteraan sempurna, kecuali jika berkumpul dalam satu kelompok dengan melakukan kerjasama untuk memperoleh manfaat dan mencegah segala sesuatu yang mengancam mereka.

Dalam kaitan tersebut, manusia - sebagai makhluk politik yang dibentuk oleh alam - yang terhimpun dalam satu negara perlu diatur dengan berbagai ketentuan yang dapat memelihara kesejahteraan manusia dalam bentuk perintah dan larangan. Begitu pula, manusia harus mematuhi pemimpin yang terpilih untuk mencapai cita-cita bersama (Jindan, 1994:43).

Dalam hal pemerintahan Al-Mawdûdi (1998:168) mengemukakan bahwa pengakuan negara terhadap kepemimpinan dan kekuasaan Allah dan rasul-Nya di bidang perundang-undangan mutlak adanya. Artinya, menyerahkan segala kekuasaan legislatif dan kedaulatan hukum tertinggi kepada kepemimpinan dan kekuasaan Allah serta dilandasi keyakinan bahwa khilafah manusia itu mewakili Allah swt. Pandangan tersebut berdasarkan Q.S Al-Mâ'idah (5):48:

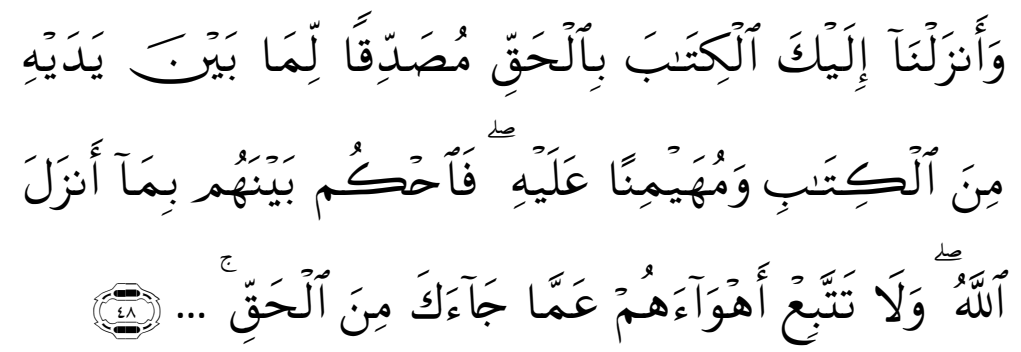

Terjemahnya:

Dan telah Kami turunkan kepadamu al-Qur'an dengan membawa kebenaran, membenarkan apa yang sebelumnya, (yaitu kitab-kitab yang diturunkan sebelumnya) dan sebagai batu ujian terhadap kitab-kitab yang lain itu. Maka putuskanlah perkara mereka menurut apa yang Allah turunkan dan janganlah kamu mengikuti hawa nafsu mereka yang meninggalkan kebenaran yang telah dating kepadamu. 
Khalifah seperti disebutkan dalam Alquran, menurut A1Mawdûdî (1998:66) adalah segala sesuatu di muka bumi ini, berupa daya dan kemampuan yang diperoleh seorang manusia hanyalah karunia dari Allah swt. Dan Allah telah menjadikan manusia dalam kedudukannya sebagai khalifah dapat menggunakan pemberianpemberian serta karunia yang Allah berikan. Karena itu, manusia bukan penguasa atau pemilik dirinya sendiri, tetapi hanyalah khalifah atau wakil Sang Pemilik yang sebenarnya. Seorang pemimpin yang menjalankan aturan dengan sistem yang terlepas dari hukum Allah, memerintah karena kepentingan sendiri ataupun golongan, maka dia bukanlah khalifah tetapi merupakan pemberontakan atau kudeta melawan Sang Penguasa yang hakiki.

Pandangan tersebut memberi pemahaman bahwa manusia hanyalah menjalankan kekuasaan di muka bumi yang pada dasarnya adalah wakil Tuhan di bumi untuk mengatur dan menjalankan hukum Allah berdasarkan petunjuk syari'ah. Manusia sama sekali tidak memiliki wewenang untuk menjalankan apalagi membuat peraturan berdasarkan atas keinginan sendiri ataupun keinginan kelompok.

Berbeda dengan pandangan Ibnu Taimiyah yang beranggapan bahwa dalam Alquran dan sunah tidak ada dasar tentang teori khalifah maupun teori imâmah yang mutlak. Al-Mawdûdî menyebutkan bahwa kekhalifahan mempunyai dasar konstitusional dalam Alquran. Ibnu Taimiyah kemudian menyerang dan mengeritik pendapat AlMawdûdî, Ibnu Taimiyah justru melihat Islam sebagai suatu tata sosial yang mempunyai hukum tertinggi, yaitu hukum Allah (Khan, 1995:143). Bagi Ibnu Taimiyah, apapun hukum Allah yang mengandung berbagai perintah kepada kaum muslimin adalah tanggung jawab yang berat dan tidak dapat dilaksanakan tanpa bantuan mekanisasi politik yang dikenal sebagai negara. Akan tetapi, Ibnu Taimiyah keberatan apabila tanggung jawab yang diterima itu dianggap sebagai otoritas ilahi yang diwakilkan kepada kita (Khan, 1995:143).

Kritik-kritik Ibnu Taimiyah terhadap teori khalifah ini kemudian membentuk versi politik refomisme-konservatif yang menghendaki digalakkannya kembali ijtihad dalam pemikiran keagamaan serta menolak dengan tegas prosedur-prosedur yang tidak kritis apalagi yang bersifat taklid. 
Pandangan senada dengan Ibnu Taimiyah dikemukakan oleh Abduh dalam Ahmad (1978:149) bahwa Islam tidak menetapkan bentuk negara. Keduanya sama-sama tidak mementingkan bentuk pemerintahan dan sama-sama berpendapat, bahwa sistem pemerintahan disesuaikan dengan kehendak umat melalui ijtihad serta tidak berdasarkan kepada syari'ah yang kaku. Pemerimtah dan rakyat mempunyai hak dan kewajiban yang sama untuk memelihara dasardasar agama, dan menafsirkannya selama masalah tersebut berkaitan dengan hal-hal keduniaan atau produk dari pemahaman itu tidak bertentangan dengan salah satu pokok-pokok agama. Artinya, merekalah yang menentukan bagaimana bentuk pemerintahan yang mereka kehendaki.

Satu hal yang menarik untuk dikaji adalah banyaknya aspek hukum yang akan muncul diakibatkan oleh perubahan-perubahan sosial yang pada hakikatnya tetap stabil meskipun ada perubahanperubahan formal. Perubahan-perubahan formal dimaksud adalah dimungkinkannya hukum Islam (syari'ah) untuk membentuk kerangka hukum umum bagi berbagai kategori dari hubungan-hubungan sosial. Asuransi misalnya adalah sebuah contoh yang relatif baru, begitu pula membeli buku secara online dari toko buku hanya sebuah metode perdagangan yang meskipun secara formal berbeda, tetapi merupakan kelanjutan dari kategori bentuk perdagangan tertentu. Jika semua bentuk kontrak yang baru memenuhi kerangka yang digariskan oleh syari'ah, hal itu dianggap sah (Vaesi, 2006:36-37).

Di samping itu, aspek-aspek lain yang penting menyangkut fleksibilitas dari hukum Islam dapat timbul dengan mempertimbangkan pesan perjanjian kontrak dan jaminan dalam konteks itu (Vaesi, 2006:36-37). Beberapa ayat suci Alquran memerintahkan umat Islam memenuhi janji jika mengadakan perjanjian (agreement), antara lain, misalnya, QS. Al-Isrâ' (17):34:

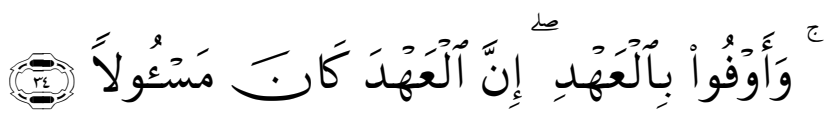

Terjemahnya:

Dan Penuhilah janji; Sesungguhnya janji itu pasti diminta pertanggungan jawabnya. 
Prinsip yang termuat dalam ayat suci tersebut memungkinkan sebuah negara, tidak terkecuali negara Islam, untuk memasuki konvensi-konvensi internasional untuk memperoleh kepentingankepentingan yang dapat diraih. Walaupun berbagai hal dari konvensi ini menyangkut bentuk yang sama sekali baru dalam hal hubungan sosial, termasuk hukum maritin misalnya atau hukum-hukum yang mengatur penerbangan dan perdagangan internasional, yang mana kasus-kasus tersebut tidak terdapat catatan (record) sebelumnya dalam syari'ah (Vaesi, 2006:38).

Dengan demikian, dalam perspektif ini, ijtihad memungkinkan seseorang untuk menarik kesimpulan terhadap masalah-masalah yang terkait dengan hukum Islam, baik masalah-masalah lama maupun baru Ini berarti bahwa fatwa-fatwa baru seputar persoalan hukum yang belum ada sebelumnya dapat melengkapi sistem hukum Islam dengan tingkat fleksibilitas yang tinggi serta memungkinkan untuk menghadapi situasi dan keadaan yang baru di abad modern ini.

Hal ini sejalan pula dengan pendapat Madjid (1994:593) bahwa pada dasarnya dalam masalah sosial politik, Islam memberi ilham bagi para pemeluknya untuk membuka wawasan dalam berbagai aspek sosial-politik. Sejarah menunjukkan pula bahwa agama Islam memberi kelonggaran besar dalam hal bentuk dan pengaturan serta teknis masalah sosial politik itu. Juga suatu bentuk formal kenegaraan tidak ada sangkut pautnya dengan masalah legitimasi para penguasanya. Yang utama adalah visi negara dipandang dari sudut pertimbangan prinsipil tentang etika sosial.

Jika demikian, membahas hubungan negara dan agama, apapun bentuk dan sistemnya bila dipandang dari sudut ibadah, sesungguhnya tergolong muamalah. Oleh karena itu, ketika bentuk dan sistem negara yang diperbincangkan, dalam waktu yang bersamaan juga telah dilakukan kebaikan bersama sesuai dengan perkembangan dan perubahan yang terjadi. Ini berarti bahwa umat Islam dapat melakukan ijtihad dan berhak memilih sekaligus menentukan hal-hal mana yang lebih sesuai dengan prinsip dan nilai-nilai universal Islam.

\section{Pengaruh Pemikiran Islam dalam Hubungan Negara dan Agama}

Pengaruh agama pada politik adalah salah satu fenomena yang terjadi di dunia Islam. Pengaruh yang amat besar dalam politik bangsa-bangsa muslim dapat dilacak dengan kecenderungan 
partisipasi politik yang amat luas di kalangan penduduk muslim (Vaesi, 2006:7).

Di sisi lain, sebagaimana dinyatakan banyak kalangan, dapat dipandang sebagai instrumen ilahi untuk memahami dunia. Alasan utama dari pandangan ini terletak pada cirri Islam yang menonjol, yaitu sifatnya yang hadir di mana-mana. Pandangan holistik terhadap Islam seperti ini melahirkan berbagai implikasi. Salah satu di antaranya ialah pandangan tersebut telah mendorong sebuah kecenderungan untuk memahami Islam dalam pengertian yang literal. Dan kecenderungan seperti ini telah dikembangkan sedemikian jauh yang menyebabkan terabaikannya dimensi kontekstual dan prinsipprinsip Islam (Efendi, 1998:7-9).

Khan (1982: 75-76) mengemukakan bahwa ada pandangan yang keliru dalam pikiran kaum muslim, ketika memahami Alquran sebagai kitab yang berisi penjelasan menyeluruh tentang segala sesuatu dengan berdasarkan terhadap ayat Alquran, QS. Al-Nahl (16):89: yaitu "Dan kami turunkan kepadamu kitab suci untuk menjelaskan segala sesuatu dan petunjuk serta rahmat dan kabar gembira bagi orang-orang yang berserah diri". Ayat ini pada prinsipnya dimaksudkan bahwa Alquran mengandung penjelasan tentang segala aspek panduan moral, dan bukan penjelasan terhadap segala objek kehidupan. Alquran tidak berisikan segala sesuatu yang berhubungan dengan pengetahuan umum.

Mencermati pemikiran yang terus berkembang dan memunculkan perdebatan sekitar hubungan negara dengan agama yang banyak menguras energi para pemikir Islam, berbagai teori mengenai hubungan negara dan agama yang mewarnai kehidupan umat Islam perlu di-review.

Term agama dan negara yang dimaksud dalam tulisan ini adalah agama dan negara dalam wujud sekarang yang sudah melembaga. Agama sebagaimana dipahami dalam pengertian aslinya adalah suatu sistem nilai/ajaran atau kesadaran moral-spritual yang diyakini benar oleh penganutnya untuk dijadikan pandangan dan pedoman hidup (Wahid dan Rumadi, 2001:23).

Bagi Islam, ajaran yang dimaksud adalah Alquran dan sunah. Namun demikian, dalam perkembangannya hingga hari ini, agama bukan saja sebagai sistem atau nilai ajaran dan kesadaran moral, tetapi telah berubah menjadi lembaga atau badan organisasi. Akibat dari 
perubahan ini, dalam tataran praktis-empiris sering terjadi hubungan yang kurang harmonis atau semacam konflik internal, baik antara sekte agama, antara agama-agama bahkan antara agama dengan negara. Ironisnya, konflik ini terkadang mengatasnamakan agama.

Dalam konteks ini, para sosiolog teoritisi politik Islam merumuskan beberapa teori tentang hubungan agama dan negara yang secara garis besar dibedakan menjadi tiga paradigma pemikiran.

Pertama, paradigma integralistik (unified paradigm). Dalam paradigm ini, agama dan negara menyatu (integrated). Wilayah agama meliputi politik atau negara. Negara merupakan lembaga politik dan keagamaan sekaligus. Oleh karena itu, menurut paradigma ini, kepala negara adalah pemegang kekuasaan agama dan kekuasaan politik sekaligus. Pemerintahannya diselenggarakan atas dasar "Kedaulatan Ilahi" karena pendukung paradigma ini meyakini, bahwa kedaulatan berasal dan berada di tangan Tuhan (Mas'udi, t.th.:4).

Sebagai lembaga politik yang didasarkan pada legitimasi keagamaan dan berfungsi menyelenggarakan "Kedaulatan Tuhan" negara dalam perspektif syari'ah bersifat teokratis yang mengandung unsur pengertian bahwa kekuasaan mutlak berada di tangan Tuhan dan konstitusi negara berdasarkan pada wahyu Tuhan (syari'ah). Sebagian kalangan sunni konservatif juga mempunyai pendapat yang sama mengenai hubungan agama dan negara ini (Wahid dan Rumadi, 2001:24).

Paradigma integralistik ini menurut Piscotory seperti dikutip Wahid (2001:25), melahirkan paham negara agama, dimana kehidupan kenegaraan diatur dengan menggunakan prinsip-prinsip keagamaan, sehingga melahirkan konsep Islam al-Dîn wa al-Dawlah (Islam agama dan sekaligus negara). Oleh Karena itu, sumber hukum positifnya adalah sumber hukum agama. Akibatnya, masyarakat tidak dapat membedakan mana aturan negara dan mana aturan agama karena keduanya menyatu. Dengan demikian, dalam paham ini, rakyat yang menaati segala ketentuan negara berarti taat kepada agama. Sebaliknya, memberontak dan melawan negara berarti melawan agama yang berarti juga melawan Tuhan.

Di sinilah penulis Barat, sejauh dikaitkan dengan Islam, sering melihat negara agama tidak compatible dengan demokrasi (Huntington, 1995:89). Demokrasi yang berangkat dari pemahaman antroposentris meniscayakan manusia menjadi pusat segala sesuatu, 
termasuk pusat kedaulatan sehingga kepala negara harus tunduk kepada kehendak dan kontrol rakyat. Sedangkan negara agama yang berangkat dari paham teosentris, menjadikan Tuhan sebagai pusat segala sesuatu.

Kedua, paradigma simbiotik (symbiotic paradigm). Agama dan Negara, menurut paradigm ini, berhubungan secara simbiotik, yaitu suatu hubungan yang bersifat timbal-balik dan saling memerlukan. Dalam hal ini, agama memerlukan negara karena dengan negara, agama dapat berkembang, demikian pula sebaliknya. Negara juga memerlukan agama karena dengan agama negara dapat berkembang dalam bimbingan etika dan moral spiritual (Wahid dan Rumadi, 2001:26).

Tampaknya di sinilah Al-Mawardi sebagai seorang teoritikus politik Islam terkemuka, bisa disebut sebagai salah satu tokoh pendukung paradigma ini. Seperti terlihat pada karya monumentalnya, al-Ah $\square$ kâm al-Sult $\square$ anniyyah. Al-Mawardi lebih mengutamakan aspek formal negara. Kecenderungan formalistik ini hampir dikatakan pragmatis, apabila dibaca pada bagian pertama kitabnya ketika membicarakan persoalan imâmah. Ia mengatakan bahwa imâmah (khalifah) merupakan lembaga penting untuk meneruskan tugas nubuwwah dalam rangka memelihara agama dan mengatur persoalan dunia. Tampaknya pernyataan tersebut yang menjadi postulasi pemikirannya. Al-Mawardi ingin meletakkan agama dalam kerangka politik dalam hubungan yang bersifat simbiotik, di mana di antara keduanya terjadi hubungan timbal-balik dan saling melengkapi (Tabroni dan Arifin, 1994:48).

Dalam paradigma simbiotik ini masih tampak adanya kehendak "mengistimewakan" penganut agama yang mayoritas untuk memberlakukan hukum-hukum agamanya di bawah legitimasi negara, atau paling tidak, karena sifatnya yang simbiotik tersebut, bahkan dalam masalah tertentu tidak menutup kemungkinan hukum agama dijadikan hukum negara.

Ketiga, paradigma sekularistik (secularistic paradigm). Paradigma ini menolak kedua paradigm di atas, yang melahirkan paradigma sekularistik dengan mengajukan pemisahan agama dari negara dan pemisahan negara dari agama. Lebih jauh Glesner, seperti dikutip Wahid (2001:28) mengatakan bahwa konsep al-dunyâ alâkhirah, al-dîn al-dawlah atau umûr al-dunyâ, umûr al-dîn 
didikhotomikan secara diamentral. Dalam konteks Islam, paradigma ini menolak determinasi Islam pada bentuk tertentu dari negara.

Lebih jauh, mereka yang berpandangan seperti ini menyatakan bahwa konsep negara agama merupakan sebuah konsep yang sudah usang dan tertinggal. Mereka menegaskan bahwa model dan sistem tersebut harus dibatasi pada zaman di mana manusia masih miskin dalam hal ilmu pengetahuan dan pengalaman dalam mengatur tertib sosialnya sehingga memerlukan agama untuk mengatur hubunganhubungan di antara mereka dalam masalah hukum, ekonomi dan kebudayaan. Rasionalitas sekuler beranggapan bahwa intelektual manusia sanggup untuk membentuk pengetahuannya sendiri tanpa bantuan wahyu. Oleh karena itu, manusia sanggup membangun ilmu pengetahuan alam dan humaniora, misalnya filsafat, hukum dan etika tanpa bantuan Tuhan ataupun agama (Vaezi, 2006:12).

Salah satu pemrakarsa paradigma sekularistik adalah Alî 'Abd al-Râziq, seorang cendekiawan muslim Mesir dalam bukunya al-Islâm wa Us $\square \hat{u l}$ al-Hukm. "Abd al-Râziq dalam Wahid dan Rumadi (2001:29) menyatakan bahwa Islam sekedar agama dan tidak mencakup urusan negara. Islam tidak mempunyai kaitan agama dengan sistem pemerintahan kekhalifahan. Menurut dia, kekhalifahan bukanlah sebuah sistem politik keagamaan atau keislaman, tetapi sebuah sistem yang sifatnya duniawi.

Paradigm sekuler ini kemudian melahirkan berbagai pertanyaan: bagaimana posisi agama dalam negara sekuler; benarkah dalam negara sekuler, yang memisahkan negara dengan agama, akan membuat negara itu tidak memperdulikan agama. Pertanyaan-pertanyaan tersebut muncul karena kesalahpahaman dalam memahami negara sekuler sehingga jawaban dari pertanyaan tersebut tidak sepenuhnya "benar". Secara konseptual, salah satu penyebabnya ialah karena bukan itu yang dimaksud dengan negara sekuler, dan secara faktual ini keliru karena hal itu tidak pernah terjadi dalam politik negara sekuler (Denny, 2000:17-18).

Sementara itu, Botrus al-Bustani (dalam Al-Jabiri, 2001:91) mengemukakan bahwa pembatas harus diletakkan antara kepemimpinan agama, yaitu kekuasaan ruhani dengan politikdan kekuasaan peradaban. Hal ini disebabkan karena sifat dan esensi kepemimpinan agama berhubungan dengan masalah-masalah batin 
yang tidak berubah dengan perubahan waktu dan kondisi. Sedangkan politik berhubungan dengan masalah-masalah lahir yang tidak permanen dan bisa berubah serta dapat diperbaiki sesuai dengan tuntutan keadaan, ruang dan waktu. Dengan demikian, mencampuradukkan antara dua kekuasaan yang sifatnya berbeda dan memiliki relasi serta term yang bertentangan, tentu saja akan menimbulkan perpecahan dan bahayanya yang nyata atas hukumhukum. Dengan demikian, tidak berlebihan jika dikatakan bahwa dalam kondisi seperti ini mustahil peradaban akan hidup dan tumbuh (Al-Jabîrî, 2001:91).

Juga dikatakan bahwa dalam Islam terdapat hukum-hukum syara yang pelaksanaannya memerlukan "Pemegang Perintah". Tetapi, tidak ada teks yang menentukan jenis pemerintahan yang harus diikuti oleh kaum muslimin, tidak ada pula teks yang melarang untuk mengikuti jenis pemerintahan tertentu (Al-Jabîrî, 2001:69-70).

Mencermati berbagai pemikiran Islam tentang hubungan antara negara dengan agama di atas, dapat dipahami bahwa pemikiranpemikiran tersebut adalah hasil ijtihad. Ijtihad dengan berbagai permasalahannya diserahkan kepada kaum muslimin yang sangat sulit menghindari perbedaan-perbedaan pendapat, bergantung kepada perbedaan masa dan situasi yang melatari pemikiran muslim itu sendiri.

\section{PENUTUP}

Pemikiran Islam tentang hubungan negara dengan agama hingga saat ini mengalami kontroversi yang masih berlanjut, meskipun pada dasarnya saling mengakui pentingnya prinsip-prinsip Islam dalam berbagai aspek kehidupan. Hal ini disebabkan karena adanya perbedaan dalam penafsiran dan kesesuaian dalam kehidupan nyata.

Terdapat tiga pola pemikiran dalam sejarah intelektual Islam dalam kaitan hubungan negara dengan agama, yaitu: (1) pendapat bahwa agama tidak semata mengatur hubungan manusia dengan Tuhan, tetapi juga suatu sistem yang mengandung ajaran lengkap termasuk kehidupan bernegara; (2) pendapat bahwa Islam sama sekali tidak berhubungan dengan urusan kenegaraan; (3) pendapat bahwa dalam dunia Islam tidak terdapat sistem kenegaraan, tetapi terdapat prinsip-prinsip nilai etika Islam dalam kehidupan bernegara. 


\section{DAFTAR PUSTAKA}

Ah mad, 'Abd al-At i Muh ammad. t.th. Al-Fikr al-Siyâsî li Imâm Muh ammad Abduh. Mesir: Al-Hay'at al-Misriyah al-Amnat li alKitâb.

Azhari, Muh. Tahir. Negara Hukum. 1992. Cet. ke-1. Jakarta: Bulan Bintang.

Denny JA. Islam. 2000. Negara Sekuler dan Demokrasi. Dalam Syarifuddin HA (Ed.). Negara Sekuler sebuah Polentik. Jakarta: Putra Berdikari Bangsa.

Departemen Agama RI. 1989. Al-Qur'an dan Terjemahannya. Semarang: Toha Putera.

Efendi, Bachtiar. Agama dan Dialog Antar Pradaban. Cet. ke-1. Jakarta: Paramadina.

al-Ghazâlî. 1956. Fad â'il al-Bat iniyyah. Leiden: t.p.

Haricahyono, Cheppy. 1986. Ilmu Politik dan Perspektifnya. Cet. ke-1. Yogyakarta: Tiara Wacana.

al-Jabîrî, Muh ammad Abî. 2001. Negara dan Penerapan. Terjemahan oleh Mujiburrahman. Yogyakarta: Fajar Pustaka Baru.

Jindan, Khalîl Ibrâhîm. 1994.Teori Pemerintahan Islam menurut Ibnu Taimiyah. Terjemahan oleh Mufi. Jakarta: PT. Rineka Cipta.

Khan, Qomaruddin. 1995. Pemikiran Politik Ibnu Taimiyah. Terjemahan oleh Anas Mahyudin. Cet. ke-2. Bandung: Pustaka.

Madjid, Nurcholis. 1994. Agama dan Negara dalam Islam; telaah atas Fiqh Siyasy Sunni. Dalam Budi Munawar Rahman (Ed.), Kontekstualisasi Doktrin Islam dalam Sejarah. Cet. ke-1. Jakarta: Yayasan Paramadina. . 1982. Political Concepts in the Qur'an. Lahore: Islamic Book Foundation.

Mas'udi, Masdar F. t.th. Agama dan Dialognya. Dalam Interfidei, Dialog, Kritik dan Identitas Agama. Yogyakarta: Dian/Interfidei

al-Mawdûdî, Abû A'la. 1998.Khalifah dan Kerajaan. Terjemahan oleh Muhammad al-Baqir. Cet. ke-4. Bandung: Mizan.

Pulungan, Suyuthi. 1997. Fiqh Siyasah Ajaran, Sejarah dan Pemikiran. Cet. ke-1. Jakarta: PT. Raja Grafindo Persada.

Tobroni dan Arifin, Syamsul. 1994. Islam Pluralisme Budaya dan Politik. Yogyakarta: SIPRESS.

Vaezi, Ahmad. 2006. Agama Politik Islam. Terjemahan oleh Ali Syihab. Cet. ke-1. Jakarta: Citra.

Wahid, Marzuki dan Rumadi. 2001. Fiqh Mazhab Negara. Cet. ke-1. Yogyakarta: LKiS. 